\title{
PRODUCTIVE AND METABOLIC RESPONSE TO TWO LEVELS OF TURNIP (Brassica rapa L.) SUPPLEMENTATION IN GRAZING DAIRY COWS DURING SUMMER
}

\author{
Claudia Barchiesi-Ferrari ${ }^{1}$, y Ricardo H. Chihuailaf ${ }^{2}$ \\ ${ }^{1}$ Universidad de La Frontera, Departamento de Producción Agropecuaria. Av. Francisco Salazar 01145, \\ Temuco. E-mail: claudia.barchiesi@ufrontera.cl \\ ${ }^{2}$ Universidad Católica de Temuco, Escuela de Medicina Veterinaria y Núcleo de Investigación en \\ Producción Agroalimentaria. E-mail: rchihuailaf@uct.cl \\ * Corresponding author E-mail: claudia.barchiesi@ufrontera.cl
}

\section{RESUMEN}

El nabo forrajero (Brassica rapa L.) es utilizado durante el verano como cultivo suplementario en vacas a pastoreo. El objetivo de este estudio fue evaluar el efecto de la suplementación estival con dos niveles de oferta de nabo forrajero en la producción de leche, y la respuesta metabólica de energía y proteína en vacas lecheras a pastoreo. Se emplearon 16 vacas Frisón Negro Chileno distribuidas aleatoriamente en dos tratamientos: dieta $A\left(2,6 \mathrm{~kg} \mathrm{DM}\right.$ vaca $\left.^{-1}\right)$ y dieta $B\left(5,1 \mathrm{~kg} \mathrm{DM} \mathrm{vaca}^{-1}\right)$. La producción de leche del grupo con la dieta $\mathrm{A}$ no presentó diferencia significativa con el grupo que recibió la dieta $B$. La proteína y grasa láctea fue similar entre los grupos $(p>0,05)$. Los dos niveles de suplementación con nabo mantuvieron un adecuado balance energético y de proteínas, reflejado en concentraciones plasmáticas de $\beta \mathrm{HB}$, proteína total, albúmina y urea que fluctuaron dentro de los intervalos de referencia. Bajo las condiciones del ensayo la respuesta productiva fue igual en ambos tratamientos, no afectando la composición láctea y manteniendo un balance energético normal. Se observó una hipofosfatemia en el tratamiento con la dieta B.

Palabras clave: respuesta metabólica, vacas lecheras, sólidos lácteos, nabo, suplementación

\section{ABSTRACT}

Forage turnip (Brassica rapa L.) is used as a supplementary feed for grazing cattle in summer. The aim of this study was to evaluate the effect of two levels of forage turnip supplementary feed on milk production, and energy and protein metabolic responses in grazing dairy cattle during summer. 16 randomly distributed Chilean Black Friesian cows were used in two treatments: diet A $(2.6 \mathrm{~kg}$ DM cow $\left.^{-1}\right)$ and diet B $\left(5.1 \mathrm{~kg} \mathrm{DM} \mathrm{cow}^{-1}\right)$. The milk production in cows fed on diet A presented no statistical difference with those fed on diet B. Milk protein and milk fat were similar between the two treatments $(p>0.05)$. Both turnip diets maintained an adequate protein and energy balance, reflected in plasma $\beta \mathrm{HB}$, total protein, albumin and urea concentrations within the reference intervals. No differences in yield responses were found between the two treatments under the study conditions. Similarly, no effects were observed on milk composition, while a normal energy balance was maintained. Hypophosphatemia was observed in cows fed on diet B.

Key words: metabolic response, dairy cows, mild solids, turnip, supplementation

Received: 05 november 2018. ～Accepted: 04 december 2018. 


\section{INTRODUCTION}

Energy is considered as the most limiting nutrient for milk production in dairy herds with feeding based on temperate grazing systems (Kolver, 2003), while N consumption in excess of requirements is frequently verified, contributing to environmental contamination (Pacheco and Waghorn, 2008). This imbalance does not favor microbial protein synthesis and leads to an increased formation of ammonium at ruminal level, which is detrimental for both the microorganisms and the ruminant (Bach et al., 2005) as it involves a high energy cost generated by the excess ammonium converted to urea in the liver (Pacheco and Waghorn, 2008).

In southern Chile, ruminant feeding is commonly based on grazing, using conserved forage in periods of poor pasture growth. Weather variations throughout the year limit the growth rate of pastures to minimum values in unfavorable months in winter or dry summer (Keim et al., 2015). The grazing systems are affected by the variations in the amount and quality of nutrients throughout the year. Therefore, the use of supplementary feeds is a strategy that can extend the grazing season and compensate for deficiencies in terms of amount or quality of nutrients.

Fast-growing forage crops, as turnip (Brassica rapa ssp. rapa), fulfill an important niche in the provision of high-quality, easily digestible feed during dry months of the year in many countries worldwide (Collett, 2014). Summer forage crops are a valuable component of a farm's feed supply as they accumulate relatively large quantities of forage dry matter (DM) (Chakwizira et al., 2014) for use in summer when pasture growth and quality is often limited by inadequate soil moisture (Hanly et al., 2017). For this reason, the use of forage turnip as a supplementary feed for dairy cows has increased during summer grazing in southern Chile. As a group, brassica plants have a much higher ratio of readily fermentable carbohydrates (i.e., water soluble sugars and pectins) to structural carbohydrates (i.e., cellulose and hemicellulose) than grass-based pastures, whereas crude protein $(\mathrm{CP})$ content is similar (Barry, 2013).

When using forage turnip during summer, the contribution of fermentable energy may increase at ruminal level, resulting in an increased milk yield by maintaining the metabolic balance. The aim of this study was to evaluate the effect of two levels of forage turnip supplementary feed on milk production, and energy and protein metabolic responses in grazing dairy cattle during summer.

\section{MATERIALS AND METHODS}

The study was conducted at the Maquehue Experimental Station of the Universidad de La Frontera, located on the central plains of the Region of La Araucanía (38 $50^{\prime}$ S; $72^{\circ} 40^{\prime}$ W), Chile. The cumulative rainfall of the year to March 26, 2013 was 84.6 mm, lower than a normal year for the area.

\section{Animals}

The experiment was conducted in summer 2013, including a pre-experimental adaptation phase of 14 days and an experimental phase of 8 days. Sixteen Chilean Black Friesian cows were used, with an average live weight of 583.6 $\mathrm{kg}$. The experimental animals had an average of 2.94 births, 151.9 days of lactation and an average daily production of $23.1 \mathrm{~L} \mathrm{cow}^{-1}$.

\section{Experimental design}

The experimental design evaluated two treatments with different supplies of forage turnip, provided through grazing: Diet A, consisting of $11 \mathrm{~kg} \mathrm{DM}$ of permanent pasture, $4.5 \mathrm{~kg}$ concentrated DM and $2.6 \mathrm{~kg}$ turnip DM; and diet B, consisting of $11 \mathrm{~kg}$ DM of permanent pasture, $4.5 \mathrm{~kg}$ concentrated $\mathrm{DM}$ and $5.1 \mathrm{~kg}$ turnip DM.

\section{Management and feeding}

During the study, the animals grazed on a permanent pasture composed of Bromus stamineus L. (48.1\%), Lolium perenne L. (20.7\%), Agrostis capillaris L. (10.3\%) and resident species $(7 \%)$. The pasture was provided in the morning through grazing after first milking $(7: 00 \mathrm{~h})$ until 12:00 $\mathrm{h}$, and after milking in the afternoon (15:00 h) until milking the following morning. The daily rotational system was calculated based on consumption of $11 \mathrm{~kg}$ DM per animal and the availability estimated using the Rising Plate Meter (RPM) (Ash Grove Plate Meter, Meter Hamilton, New Zealand) before conducting the study. At 12:00 h, each experimental group was transferred to the corresponding turnip plots until milking at 15:00 h, with a surface of $3 \mathrm{~m}^{2} \mathrm{cow}^{-1}$ equivalent to $2.6 \mathrm{~kg}$ of $\mathrm{DM}$ for the diet $\mathrm{A}$, and $6 \mathrm{~m}^{2} \mathrm{cow}^{-1}$ equivalent to $5.1 \mathrm{~kg} \mathrm{DM}$ for the diet B. After the afternoon milking, the cows grazed on the permanent pasture until morning milking. The concentrate given to the cows was prepared on site and consisted of oats (Avena sativa L.) $(61.03 \%)$, triticale $(\times$ Triticosecale Wittmack Camus) (32.86\%), urea (1.88\%), mineral salts $(3.29 \%)$ and common salt $(0.94 \%)$, supplied during milking, with $4.45 \mathrm{~kg} \mathrm{DM} \mathrm{d}^{-1}$. 


\section{Sample collection}

Samples were extracted on the permanent pasture with the cutting method to determine DM and botanical composition; for turnips, six whole plants per treatment were extracted to determine the DM. Also, a sample composed of concentrate from the site was taken. All the feed samples were collected on day four of the experiment.

Milk production was measured per cow on day one and eight (final stage) of the experiment, both during the morning milking $(07: 00 \mathrm{~h})$, using a milking machine (Waikato, Alfa Laval, Hamilton, New Zeland). On both days, four samples per treatment were collected in plastic bottles from the same animal, using preservatives for later analysis.

Individual blood samples were extracted on days one and eight after the morning milking. These samples were taken using heparin vacuum tubes from the animal's coccygeal vein to obtain the plasma.

\section{Feed analysis}

Pasture, forage turnip and concentrate were analyzed: DM (AOAC, 1996), CP (analyzed using the LECO FP 528 analyzer (LECO Corporation, St Joseph, USA), based on the method of DUMAS (AOAC, 1996), ME was estimated by regression from the $\mathrm{D}$ value (organic matter in the dry matter) determined in vitro (Goering and Van Soest, 1972), ash (Ash) (AOAC, 1996, method 942.05), neutral detergent fiber (NDF) (Van Soest et al., 1991) and acid detergent fiber (ADF) (AOAC, 1996, method 973.18).

\section{Milk analysis}

Milk was analyzed for fat content and milk protein content in $\mathrm{g} \mathrm{kg}^{-1}$ using the IR method, IDF-FIL standard 141C:2000 (IDF, 2000).

\section{Blood analysis}

Total protein concentration in plasma was determined using the method of Biuret at 550 $\mathrm{nm}$. The albumin determination was done with the colorimetric method at $550 \mathrm{~nm}$. Urea was determined by the kinetic enzymatic method at $340 \mathrm{~nm}$. The plasma cholesterol concentration was measured using a commercial reagent (Cholesterol@, Human). In addition, the $\beta-\mathrm{OH}$ butyrate concentration was determined using a commercial reagent (Ranbut ${ }^{\circledR}$, Randox Laboratories, Crumlin, Ireland).

The plasma calcium concentration $(\mathrm{Ca})$ was determined with a commercial reagent (Ca-color arsenazo $\mathrm{III}{ }^{\circledR}$, Wiener). The plasma phosphorus concentration $(\mathrm{P})$ was determined with a commercial reagent (Phosphorus liquicolor ${ }^{\circledR}$, Human). The plasma magnesium concentration $(\mathrm{Mg})$ was determined using a colorimetric technique with a commercial reagent (Magnesium liquicolor ${ }^{\circledR}$, Human). The $\mathrm{Ca} / \mathrm{P}$ ratio was obtained using the quotient between the plasma concentrations of the two elements. The mineral concentration was expressed in mmol L $\mathrm{L}^{-1}$. The activity of the enzyme aspartate aminotransferase (AST) was determined with a commercial reagent (ASAT IFCC liquiUV ${ }^{\circledR}$, Human) and was expressed in $\mathrm{U} \mathrm{L}^{-1}$. All the photometric measurements were determined in a biochemical autoanalyzer (Metrolab 2300 Plus, Wiener Lab Group, Argentina).

\section{Statistical analysis}

The normality and homoscedasticity of the data were evaluated through Shapiro-Wilk tests and Bartlett's test, respectively. Student's t-test for independent samples was used for comparing mean values. The AST activity and urea concentration were converted to natural logarithm values before analysis. A p value less than 0.05 was considered significant.

\section{RESULTS AND DISCUSSION}

\section{Chemical composition of the feed}

The nutritional composition of the feed used is shown in Table 1. The pasture used during the study is permanent; its nutritional composition is comparable to a summer without drought. Araya et al. (2012) reported that the DM of the pasture can vary between 120 and $300 \mathrm{~g} \mathrm{~kg}^{-1}$, with average $\mathrm{CP}$ values of $180 \mathrm{~g} \mathrm{~kg}^{-1}$ and ME values of $2.6 \mathrm{Mcal}$ $\mathrm{kg}^{-1}$, similar to those obtained in this analysis (183 $\mathrm{g} \mathrm{kg}^{-1}$ of CP and $2.5 \mathrm{Mcal} \mathrm{kg}^{-1}$ of ME). In the pasture, the observed values of $216.8 \mathrm{~g} \mathrm{~kg}^{-1}$ of DM and $504.4 \mathrm{~g} \mathrm{~kg}^{-1}$ of NDF are normal for the time of year. According to Parga (2003), the nutrient content of the pasture during summer can vary widely depending on the climate conditions. Pastures with adequate management during the summer have a nutritional composition with average values ranging from 220 to $280 \mathrm{~g} \mathrm{~kg}^{-1}$ of $\mathrm{DM} ; 120$ to $150 \mathrm{~g} \mathrm{~kg}^{-1}$ of CP; 2.2-2.5 Mcal kg-1 of $\mathrm{ME}$, and 500 to $600 \mathrm{~g} \mathrm{~kg}^{-1}$ of NDF. Canto (2011) performed a similar analysis in a summer with low rainfall and no irrigation, reporting similar values for $\mathrm{CP}$ and NDF, but a smaller content of ME and a higher level of DM. Conversely, Barrientos (2012) obtained higher nutritional values during a wet summer.

The availability of turnip during the study was $8.5 \mathrm{t} \mathrm{ha}^{-1}$, which is greater than the $5.2 \mathrm{t} \mathrm{ha}^{-1}$ in dry land and slightly less than the $9.3 \mathrm{t} \mathrm{ha}^{-1}$ obtained with irrigation by Rowe and Neilsen (2010) in Tasmania, Australia. The average CP content between treatments was $203 \mathrm{~g} \mathrm{~kg}^{-1}$. This value was 
Table 1. Chemical composition of pasture, turnip and concentrate (DM). Experiment of turnip supply to dairy cows.

\begin{tabular}{lccccc}
\hline & \multicolumn{2}{c}{ Pasture } & \multicolumn{2}{c}{ Turnip (whole plant) } & Concentrate \\
\cline { 2 - 6 } & Diet A & Diet B & Diet A & Diet B & Diet A and Diet B \\
\hline $\mathrm{DM}, \mathrm{g} \mathrm{kg}^{-1}$ & 216.8 & 216.7 & 92.7 & 77.4 & 896.5 \\
$\mathrm{CP}, \mathrm{g} \mathrm{kg}^{-1}$ & 187.3 & 178.6 & 216.1 & 188.8 & 138.5 \\
$\mathrm{ME}, \mathrm{Mcal} \mathrm{kg}^{-1}$ & 2.38 & 2.62 & 2.62 & 2.46 & 2.36 \\
$\mathrm{NDF}, \mathrm{g} \mathrm{kg}^{-1}$ & 497.9 & 510.9 & 270.0 & 283.6 & 264.9 \\
$\mathrm{CHSO}, \mathrm{g} \mathrm{kg}^{-1}$ & - & - & 100.57 & 83.51 & - \\
${\text { Ash, } \mathrm{g} \mathrm{kg}^{-1}}^{9}$ & 98.7 & 101.7 & 98.7 & 101.7 & 50.0
\end{tabular}

DM: Dry matter; CP: Crude protein; ME: Metabolizable protein; NDF: Neutral detergent fiber; CHSO: Soluble carbohydrates.

lower than the $230 \mathrm{~g} \mathrm{~kg}^{-1}$ obtained by Barrientos (2012), but greater than the $130 \mathrm{~g} \mathrm{~kg}^{-1}$ reported by Sun et al. (2012) and the $171.9 \mathrm{~g} \mathrm{~kg}^{-1}$ reported by Anrique et al. (2014). This high CP content can be attributed to the crop having undergone some type of water stress during the growth stage of the plant (Eckard et al., 2001). The high NDF content $\left(276.8 \mathrm{~g} \mathrm{~kg}^{-1}\right)$ slightly exceeded the $260 \mathrm{~g}$ $\mathrm{kg}^{-1}$ reported by Anrique et al. (2014), attributable to the ripeness of the crop, since some plants were beginning to flower. In this study, ME values (2.54 Mcal kg-1 DM) were lower than those reported by Anrique et al. (2014) and Demanet (2014), but similar to the values obtained by Barrientos (2012).

\section{Milk production.}

Milk production (Table 2) was similar ( $\mathrm{p}>0.05)$ between the treatments. Parga et al. (2009) used $5 \mathrm{~kg}$ DM of turnip, obtaining a lower yield (20.3 L) compared to diet B (22.6 L) in this study. The most common levels of turnip supplementation are up to $5 \mathrm{~kg}$ DM per animal (Pulido et al., 2011), which can explain that there was no difference in production. In addition, Barrientos (2012) used 4 $\mathrm{kg}$ DM of turnip feed, and reported a yield value that was similar $(22.3 \mathrm{~L})$ to that obtained in diet B. Diet A would lead to a decrease in output to values below $20 \mathrm{~L} \mathrm{~d}^{-1}$, as was the case of $\operatorname{diet} \mathrm{A}$ at the end of the study; this is the point at which turnip level would be insufficient to sustain the requirements since the yield was 18.89 L. Brassica plants have a much higher ratio of readily fermentable carbohydrates (i.e.,water soluble sugars and pectins) to structural carbohydrates (i.e., cellulose and hemicellulose) than grassbased pastures, whilst crude protein content is similar (Barry, 2013), and therefore they allow better synchrony between energy and protein in the rumen. This would explain that a smaller ingestion of turnip limits milk production. In this sense, Aucal et al. (2015), when analyzing the use of forage turnip on 35 dairy farms in southern Chile, concluded that the amount of turnip in the diet was not related to the milk yield, and that the consumption of DM and energy were the factors that best explained the yield response. This agrees with our results since no statistical differences in yield were observed between treatments.

\section{Milk composition.}

Milk protein content (Table 2 ) was similar ( $p>$ 0.05 ) in both treatments. This is in agreement with Canto (2011) and Barrientos (2012), who obtained 300 and $318 \mathrm{~g} \mathrm{~kg}^{-1}$, respectively. Milk fat had no differences $(p>0.05)$ between the treatments, only a slight increase between the beginning and end of the experiment. This increase can be explained by the fat content being more concentrated, given the reduction in milk yield.

Table 2. Milk production, protein and fat contents in the different treatments (mean \pm standard deviation). Experiment of turnip supply to dairy cows.

\begin{tabular}{lcrrr}
\hline & \multicolumn{2}{c}{ Starting stage } & \multicolumn{2}{c}{ Final stage } \\
\cline { 2 - 5 } & Diet A & \multicolumn{1}{c}{ Diet B } & \multicolumn{1}{c}{ Diet A } & \multicolumn{1}{c}{ Diet B } \\
\hline Milk production, L & $22.8 \pm 3.06^{\text {a }}$ & $23.17 \pm 2.34^{\text {a }}$ & $19.88 \pm 3.48^{\text {a }}$ & $22.63 \pm 3.79^{\text {a }}$ \\
Protein, g kg-1 & $32.8 \pm 0.40^{\text {a }}$ & $29.5 \pm 0.21^{\text {a }}$ & $32.3 \pm 0.49^{\text {a }}$ & $29.5 \pm 0.28^{\text {a }}$ \\
Fat, g kg-1 & $36.4 \pm 0.52^{\text {a }}$ & $32.6 \pm 0.53^{\text {a }}$ & $39.1 \pm 0.85^{\text {a }}$ & $36.9 \pm 0.32^{\text {a }}$ \\
\hline
\end{tabular}

Different letters in the rows indicate statistical differences $\mathrm{p}<0.05$. 


\section{Metabolic response.}

No differences were observed in terms of mean AST plasma activity during this study $(\mathrm{p}>0.05)$ (Table 3). The values are below the reference limit $\left(<150 \mathrm{U} \mathrm{L}^{-1}\right)$ for the species (Wittwer, 2012). This semi-specific enzyme is located in the hepatocyte and other organs; however, an increase in plasma activity over the upper reference limit indicates (from a clinical point of view) damage to the hepatic parenchyma in the absence of muscular alterations (Wittwer, 2012). In this study, the experimental animals did not present acute hepatic alterations that could compromise their metabolic health and, therefore, the results. The most common levels of turnip supplementation are up to $5 \mathrm{~kg}$ DM per animal (Pulido et al., 2011). Studies with rapeseed oil meal as a source of glucosinolates have shown that feed intake, live weight gain and fertility were negatively affected (Tripathi and Mishra, 2007). The secondary compounds that occur in forage brassicas, their degradation/metabolism in the ruminant digestive system and the absorbed products can have negative effects on grazing animals (Barry, 2013). The main risks are associated with nitrate accumulation and the presence of glucosinolates and methyl cysteine sulfoxide in the forage, which could cause hepatic damage, goiters and hemolytic anemia (Pulido et al., 2011; Barry, 2013).

The total protein plasma concentrations (Table 3) were similar $(p>0.05)$ between diets $A$ and $B$. The average recorded values in the study are within the interval $\left(62\right.$ to $\left.82 \mathrm{~g} \mathrm{~L}^{-1}\right)$ indicated for the species (Wittwer, 2012). Likewise, the albumin plasma concentration (Table 3) was similar ( $p>$ 0.05 ) between treatments. The average albumin concentration remained within the reference interval (29 to $41 \mathrm{~g} \mathrm{~L}^{-1}$ ) for the species during the study (Wittwer, 2012). Both biomarkers, albumin and total protein, are used to evaluate the metabolic balance of the proteins. Albumin is the most abundant protein in the blood plasma. It is synthesized in the liver, and its concentration is in direct relation to the protein contribution of the ration and the capacity for hepatic synthesis (Eckersall, 2008). Since these metabolites did not suffer modifications in their concentration, we could say that the ration was appropriate to cover the animal's requirements; however, it must be remembered that these metabolites, particularly albumin, do not reflect sudden metabolic changes in the short-term given their mean life, which is 21 days in a bovine.

The plasma urea concentration was similar between treatments $(p>0.05)$ (Table 3$)$. All the urea concentrations were within the reference interval (2.6 to $7.0 \mathrm{mmol} \mathrm{L}^{-1}$ ) indicated for the species (Wittwer, 2012). The plasma $\beta-\mathrm{OH}$ butyrate concentrations (Table 3 ) were similar ( $p>$ 0.05 ) between diets A and B. The values obtained in both treatments are below the upper reference limit ( $<$ to $0.60 \mathrm{mmol} \mathrm{L}^{-1}$ ) indicated for the species (Wittwer, 2012).

$\beta-\mathrm{OH}$ butyrate is an endogenous metabolite that also derives from ingestion as a pre-formed component in certain foods, an indicator of energy balance (Chilliard et al., 1995). Managing diets that do not cover the animal's energy requirements triggers the mobilization of triacylglycerols from the fat reserves to obtain energy. Free fatty acids are $\beta$-oxidized in the liver and skeletal muscle to form acetyl-CoA, which enters the Krebs cycle (Roche et al., 2009). When the oxaloacetate availability in the liver is insufficient to dock onto all the acetyl-CoA molecules from $\beta$-oxidation, acetyl-CoA diverts to the metabolic pathway to synthesize ketone bodies as $\beta$-OH butyrate, acetate and acetoacetate (Bruss, 2008). In this study, the $\beta-\mathrm{OH}$ butyrate concentrations made it possible to establish that turnip feed did not affect the energy balance, keeping it in a state considered adequate (Wittwer, 2012).

Parga et al. (2010) and Barrientos (2012) conducted studies using turnip, reporting mean concentrations of $\beta-\mathrm{OH}$ butyrate of $0.74(\mathrm{mmol}$ $\left.\mathrm{L}^{-1}\right)$ and $0.75\left(\mathrm{mmol} \mathrm{L}^{-1}\right)$, repectively, which were higher than those observed in this study. At ruminal level, an adequate energy contribution in relation to the degradable protein is reflected

Table 3. Concentration of plasma metabolites (mean \pm standard deviation) for each treatment, and time effect. Experiment of turnip supply to dairy cows.

\begin{tabular}{|c|c|c|c|c|}
\hline & \multicolumn{2}{|c|}{ Starting stage } & \multicolumn{2}{|c|}{ Final stage } \\
\hline & Diet A & Diet B & Diet A & Diet B \\
\hline Urea, $\mathrm{mmol} \mathrm{L}^{-1}$ & $5.64 \pm 0.79 a$ & $5.72 \pm 1.28^{a}$ & $5.42 \pm 0.26^{a}$ & $6.23 \pm 1.05^{a}$ \\
\hline Total protein, $\mathrm{g} \mathrm{L}^{-1}$ & $77.64 \pm 7.83^{a}$ & $75.09 \pm 2.77 \mathrm{a}$ & $77.68 \pm 1.65^{\text {a }}$ & $74.69 \pm 6.28^{a}$ \\
\hline Albumin, $\mathrm{g} \mathrm{L}^{-1}$ & $39.54 \pm 3.14^{\mathrm{a}}$ & $37.49 \pm 2.34^{a}$ & $39.14 \pm 2.54^{a}$ & $39.20 \pm 3.58^{a}$ \\
\hline$\beta-\mathrm{OH}$ butyrate, $\mathrm{mmol} \mathrm{L}^{-1}$ & $0.38 \pm 0.10^{a}$ & $0.33 \pm 0.09$ a & $0.31 \pm 0.03$ a & $0.32 \pm 0.06^{\mathrm{a}}$ \\
\hline Cholesterol, mmol L-1 & $6.64 \pm 1.23^{a}$ & $6.30 \pm 1.40 \mathrm{a}$ & $6.45 \pm 1.14^{a}$ & $6.00 \pm 1.24^{a}$ \\
\hline
\end{tabular}

Different letters in the rows indicate statistical differences $\mathrm{p}<0.05$. 
in the urea concentrations. Urea concentrations depend not only on the protein contribution of the ration, but also on the degradable protein:energy synchrony in the rumen. High urea concentrations indicate an energy deficiency or asynchronism between protein degradability in the rumen and energy of the ration. No treatment affected the concentration of this metabolite; the values were within the reference interval, which indicates a synchronization between the energy released by the fermentable degradation of carbohydrates and the degradable protein at ruminal level (Wittwer, 2012). Parga et al. (2010) obtained plasma urea values of $8.5 \mathrm{mmol} \mathrm{L}^{-1}$, while Barrientos (2012) reported a value of $9.49 \mathrm{mmol} \mathrm{L}^{-1}$. This better synchronization between energy and degradable protein is explained by the fact that turnip generally has a higher amount of easily fermentable carbohydrates than structural ones (Barry, 2013). Based on the high solubility of its protein, this attains a ruminal degradable protein:energy synchrony similar to that obtained with the use of concentrates. In herbivores, cholesterol is predominantly endogenous, synthesized in various tissues from acetyl-CoA and considered an indicator of the fiber contribution and energy balance (Cavestany et al., 2005).

In this study, the average cholesterol concentration did not differ between treatments. The values recorded in this study are over the upper reference limit ( 2.7 to $\left.5.3 \mathrm{~g} \mathrm{~L}^{-1}\right)$. The high cholesterol concentration is commonly attributed to lipid mobilization when the energy demand is greater than that supplied in the diet; however, the other indicators of energy balance in this study are within the reference interval and do not reflect an energy imbalance. Hypercholesterolemia may be due to the high NDF of the diet associated with an increase in the synthesis of plasma lipoproteins and the progress of lactation.

The mineral metabolic balance of the experimental groups is shown in Table 4. The plasma calcium concentration was similar $(\mathrm{p}>$ 0.05) in the two treatments. The mean calcium concentration remained within the reference interval (2.0 to $2.6 \mathrm{mmol} \mathrm{L}^{-1}$ ) (Wittwer, 2012). The plasma phosphorus concentration fell in the animals fed on diet $B$ at the end of the study ( $p$ $=0.034$ ), recording a mean value below the limit of the interval given for bovines (1.0 to $2.3 \mathrm{mmol}$ $\left.\mathrm{L}^{-1}\right)$. The plasma magnesium concentration was not altered by the treatments; all the groups presented average values above the reference limit ( 0.6 to $1.1 \mathrm{mmol} \mathrm{L}^{-1}$ ). The calcium/phosphorus ratio increased significantly in both treatments at the end of the study ( $p=0.0004)$. Forage turnip has a low phosphorus content in its leaves, and a high content of calcium and other minerals, among them potassium; this conditions a high $\mathrm{Ca} / \mathrm{P}$ ratio in the animal, which, if prolonged, leads to an increase in the risk of bone problems and fractures (Reid et al., 1994). The calcium concentration in the blood is subject to a strict hormonal control, unlike phosphorus, which is why phosphatemia has a greater fluctuation, being a better biomarker of its contribution to the diet. The reduction in magnesemia observed in the animals fed on diet $B$ at the end of the study may be attributed to the high potassium contribution that turnip supplies. The potassium at ruminal level limits the absorption of magnesium, since it reduces the magnesium transport from the rumen to the blood. Just like phosphatemia, magnesemia is variable when not subject to hormonal control, thus being a reflection of the digestive absorption and the excretion through urine and milk.

\section{CONCLUSIONS}

The use of forage turnip as a supplementary feed maintained milk yield in dairy cows grazing on permanent pastures, with no differences between treatments in the study period. A nonsignificant lower yield was observed towards the end of the study in the group fed on the diet with lower turnip contribution. Both treatments maintained protein and milk fat levels in addition to an adequate energy and protein metabolic balance. Turnip supply caused an imbalance in the $\mathrm{Ca} / \mathrm{P}$ ratio in the animal towards the end of the

Table 4. Mineral concentration and $\mathrm{Ca} / \mathrm{P}$ ratio in plasma (mean \pm standard deviation) in each treatment, and time effect. Experiment of turnip supply to dairy cows.

\begin{tabular}{lcccc}
\hline & \multicolumn{2}{c}{ Starting stage } & \multicolumn{2}{c}{ Final stage } \\
\cline { 2 - 5 } & Diet A & Diet B & Diet A & Diet B \\
\hline $\mathrm{Ca}, \mathrm{mmol} \mathrm{L}^{-1}$ & $2.26 \pm 0.14^{\mathrm{a}}$ & $2.17 \pm 0.19^{\mathrm{a}}$ & $2.33 \pm 0.17^{\mathrm{a}}$ & $2.34 \pm 0.13^{\mathrm{a}}$ \\
$\mathrm{P}, \mathrm{mmol} \mathrm{L}^{-1}$ & $1.18 \pm 0.09^{\mathrm{a}}$ & $1.02 \pm 0.08^{\mathrm{a}}$ & $1.01 \pm 0.10^{\mathrm{a}}$ & $0.96 \pm 0.18^{\mathrm{b}}$ \\
$\mathrm{Ca} / \mathrm{P} \mathrm{ratio}_{\mathrm{Mg}, \mathrm{mmol} \mathrm{L}^{-1}}$ & $1.94 \pm 0.22^{\mathrm{a}}$ & $2.13 \pm 0.16^{\mathrm{a}}$ & $2.31 \pm 0.13^{\mathrm{b}}$ & $2.49 \pm 0.35^{\mathrm{b}}$ \\
\hline
\end{tabular}

Different letters in the rows indicate statistical differences $\mathrm{p}<0.05$. 
study. If this condition is prolonged alterations in health could be observed.

\section{ACKNOWLEDGEMENTS}

This research was funded by Project DI12-0023 of the Research Office of the Universidad de La Frontera, Temuco, Chile.

\section{LITERATURE CITED}

Anrique, R., X. Molina, M. Alfaro, y R. Saldaña. 2014. Composición de alimentos para el ganado bovino. $4^{a}$ ed. 91 p. Fundación para la Innovación Agraria (FIA), Ministerio de Agricultura. Universidad Austral de Chile, Facultad de Ciencias Agrarias, Valdivia, Chile.

Araya, R., O. Balocchi, C. Canales, K. Contreras, N. Díaz, P. Gaete, et al. 2012. Manejo eficiente del pastoreo: La pradera como alimento. 51 p. Imprenta América, Osorno, Chile.

AOAC. 1996. Official Methods of Analysis. Association of Official Analytical Chemist (AOAC). 937 p. 16th ed. Gaithersburg, Virginia, USA.

Aucal, S., O.A. Balocchi, and J.P. Keim. 2015. Inclusión del nabo forrajero (Brassica rapa) como suplemento estival en dietas ofrecidas a vacas lecheras en predios de la Provincia de Ranco. Agro Sur (Chile) 43:9-18.

Bach, A., S. Calsamiglia, and M.D. Stern. 2005. Nitrogen metabolism in the rumen. J. Dairy Sci. 88 (E. Suppl.):E9-E21. doi: 10.3168/jds. S0022-0302(05)73133-7.

Barry, T.N. 2013. The feeding value of forage brassica plants for grazing ruminant livestock. Anim. Feed Sci. Tech. 181:15-25. doi: 10.1016/j.anifeedsci.2013.01.012.

Barrientos, L. 2012. Efecto de la suplementación con nabo forrajero (Brassica rapa L.) o concentrado sobre la respuesta productiva y metabólica de vacas lecheras en pastoreo estival. Tesis de Magíster. Facultad Medicina Veterinaria. Universidad Austral de Chile, Valdivia, Chile.

Bruss, M. 2008. Lipids and ketones. p. 81-115. In Kaneko, J., J. Harvey, M. Bruss (eds.). Clinical Biochemistry of Domestic Animals. 6th ed. Academic Press, San Diego, California, USA.

Canto, F. 2011. Efecto de la suplementación estival con nabo forrajero (Brassica rapa L.) sobre la condición corporal, peso vivo, producción y composición de leche en vacas lecheras a pastoreo. Tesis Médico Veterinario. Facultad de Medicina Veterinaria, Universidad Austral de Chile, Valdivia, Chile.
Cavestany, D., J.E. LeBlanc, M. Kulcsar, G. Uriarte, P. Chilibroste, A. Meikle, et al. 2005. Studies of the transition cow under a pasture-based milk production system: metabolic profile. J. Vet. Med. A 52:1-7. doi: 10.1111/j.14390442.2004.00679.x.

Chakwizira, E., S. Sinton, J.B. Reid, R.F. Zyskowski, and E.D. Meenken. 2014. The ballance agri-nutrients brassica calculatorimprovement of the turnip model. Agron. N.Z. 44:37-47.

Chilliard, Y., M. Doreau, F. Bocquier, and G.E. Lobley. 1995. Digestive and metabolic adaptations of ruminants to variations in food supply. p. 329-360. En Journet, M., E. Grenet, M.H. Farce, M. Theriez, C. Demarquilly (eds.). Recent Developments in the Nutrition of Herbivores. Proc. IV ${ }^{\text {th }}$ International Symposium on the Nutrition of Herbivores. INRA, Paris, France.

Collett, M.G. 2014. Bile duct lesions associated with turnip (Brassica rapa) photosensitization compared with those due to Sporidesmin toxicosis in dairy cows. Vet. Pathol. 51:986991. doi: $10.1177 / 0300985813513042$.

Demanet, R. 2014. Manual de especies forrajeras. 2a . ed. Watt's, Osorno, Chile.

Eckard, R.J., A. Salardini, M. Hannah, and D. Franks. 2001. The yield, quality and irrigation response of summer forage crops suitable for a dairy pasture renovation program in northwestern Tasmania. Aust. J. Exp. Agric. 41:3744.

Eckersall, P.D. 2008. Proteins, proteomics, and the dysproteinemias. p. 117-155. In Kaneko, J., J. Harvey, M. Bruss (eds.). Clinical Biochemistry of Domestic Animals. 6th ed. Academic Press, San Diego, California, USA

Goering, H., and P. Van Soest. 1972. Forage fiber analyses (apparatus, reagents, procedures, and some applications). Agric. Handbook No. 379. Agricultural Research Service (ARS), USDA, Washington DC, USA.

Hanly, J.A., M.J. Hedley, and D.J. Horne. 2017. Effects of summer turnip forage cropping and pasture renewal on nitrogen and phosphorus losses in dairy farm drainage waters: A threeyear field study. Agr. Water Manage. 181:1017. doi.org/10.1016/j.agwat.2016.11.009.

IDF. 2000. Standard 141C:2000. Whole milkdetermination of milk, fat, protein and lactose content. Guidance on the operation of mid-infrared instruments. $15 \mathrm{f}$. International Dairy Federation (IDF), Bruxelas, Belgium. 
Keim, J.P., I.F. López, and O.A. Balocchi. 2015. Sward herbage accumulation and nutritive value as affected by pasture renovation strategy. Grass and Forage Sci. 70:283-295. doi.org/10.1111/gfs.12115.

Kolver, E.S. 2003. Nutritional limitations to increased production on pasture-based systems. Proc. Nutrition Soc. 62:291-300

Pacheco, D., and G.C. Waghorn. 2008. Dietary nitrogen-definitions, digestion, excretion and consequences of excess for grazing ruminants. Proc. New Zealand Grassland Association 70:107-116.

Parga, J. 2003. Utilización de praderas y nutrición de vacas a pastoreo. En Teuber, N., H. Uribe, L. Opazo (eds). Seminario: Hagamos de la lechería un mejor negocio. Serie Actas № 24. INIA, Centro Regional de Investigación Remehue, Osorno, Chile.

Parga, J., F. Lanuza, R. Pulido, O. Balocchi, F. Canto, S. Campo, et al. 2009. Suplementación estival de vacas lecheras a pastoreo con nabo forrajero (Brassica rapa L.). p. 73-74. Libro de Resúmenes. XXXIV Congreso de la Sociedad Chilena de Producción Animal (SOCHIPA), Pucón, Chile.

Parga, J., L. Barrientos, R. Pulido, F. Canto, F. Lanuza, O. Balocchi, and C. Uribe. 2010. Suplementación estival de vacas lecheras a pastoreo con nabo forrajero (Brassica rapa $\mathrm{L}$.): respuesta productiva. p. 117-118. Resúmenes del XXXV Congreso Anual de la Sociedad Chilena de Producción Animal, Coyhaique. Chile.

Pulido, R., J. Parga, F. Lanuza, and O. Balocchi. 2011. Suplementación de vacas lecheras a pastoreo: Suplementos alimenticios. Consorcio Lechero, Osorno, Chile.
Reid, R., J. Puoli, G. Jung, J. Cox-Ganser, and A. McCoy. 1994. Evaluation of Brassicas in grazing systems for sheep: I. Quality of Forage and Animal Performance. J. Anim. Sci. 72:1823-1831.

Roche, J.R., N.C. Friggens, J. Kay, M. Fisher, K. Stafford, and D. Berry. 2009. Invited review: body condition score and its association with dairy cow productivity, health and welfare. J. Dairy Sci. 92:5769-5801. doi: 10.3168/jds.20092431.

Rowe, B.A., and J.E. Neilsen. 2010. Effects of irrigating forage turnips, Brassica rapa var. rapa, during different periods of vegetative growth. 1. Turnip yields, yield components and growth rates. Crop and Pasture Sci. 61:885-891. doi.org/10.1071/cp10075.

Sun, X.Z., G.C. Waghorn, S.O. Hoskin, S.J. Harrison, S. Muetzel, and D. Pacheco, 2012. Methane emissions from sheep fed fresh brassicas (Brassica spp.) compared to perennial ryegrass (Lolium perenne). Anim. Feed Sci. Technol. 176:107-116

Tripathi, M.K., and A.S. Mishra. 2007. Glucosinolates in animal nutrition: a review. Anim. Feed Sci. Tech. 132:1-27. doi. org/10.1016/j.anifeedsci.2006.03.003.

Van Soest, P., J. Robertson, and B Lewis. 1991. Methods for dietary fiber, neutral detergent fiber, and nonstarch polysaccharides in relation to animal nutrition. J. Dairy Sci. 74:3583-3597. doi:10.3168/jds.S00220302(91)78551-2.

Wittwer, F. 2012. Manual de Patología Clínica Veterinaria. $2^{\mathbf{a}}$ ed. Imprenta América, Valdivia. Chile. 